\title{
СЛОГАН ДЛЯ РЕКЛАМЫ СМИ (ГАЗЕТЫ)
}

ALŽBETA DZURKOVÁ VIROSTKOVÁ

\section{ADVERTISING SLOGAN IN MASS MEDIA}

ABSTRACT One of the components of the language of advertisements is its slogan. Attention catching phrases appear in an advertising slogan in order to attract the advertised product. An element that brings attention to itself is also known as an "invitation" element. This is a special method of print media: a collocation, phrase, word or its part. Sometimes the "invitation" element can stand for a company's name. According to the degree of objectivity and the nature of information, we distinguish between informative and culturo-lingual slogans.

KEY WORDS slogan, mass media, precedent text, lingvoculturology, newspaper headline, daily press

CONTACT Vysoká škola medzinárodného podnikania ISM Slovakia v Prešove;

betka.dzurkova@gmail.com 
Печатная реклама зависит от ряда факторов. В большой степени от слогана (англ. "slogan" - лозунг, зазыв) - вводная, лидинговая (англ. "to lead" - вести) фраза, которая обычно графически выделяется. Существуют работы, лингвистически трактующие рекламную практику (Розенталь, Кохтев) и др.

В упомянутой рекламе сам процесс восприятия рекламы рассматривается как двоякий, активно-пассивный со стороны потребителя. Эмоциональный процесс восприятия рекламы пассивен, так как зависит от внешнего воздействия и от внутреннего состояния реципиента рекламного текста. Но в то же время он активен, так как побуждает человека к какой-либо деятельности. Реклама же в свою очередь должна вызывать у адресата представление о предмете и связанные с ним ассоциации, формировать сам рекламный образ. Она должна давать максимум информации при минимуме слов.

О рекламных слоганах (у авторов «загаловки») говорится, что им отводится важная роль, так как замечено, что их читает в 5 раз больше людей, чем текст. Они должны привлекать внимание к объявлению, сообщать минимум информации, заинтересовывать читателя, побуждать его прочитать весь текст объявления, помочь понять выгодность, пользу, приемлемость предложения. Но феномен слогана требует большего внимания, поэтому целесообразно остановиться именно на нем.

Слоган несет не столько смысловую, денотативную (минимум информации, у Розенталя и Кохтева), сколько аттрактивную, привлекательную нагрузку. Именно аттракция является его базисной функцией. Это подтверждается возможностью существования слоганов, вводных фраз рекламы, содержащих иностранные лексемы или лексемы в латинской графике. Например, слоган, явно отсылающий к политическому лозунгу (Каждой советской семье к 2000 году отдельную квартиру или дом). Нельзя не отметить их аттрактивное сходство: Каждой российской семье к 2000 году качественный струйный принтер EPSON Stylus Color 300. Из решений рекламного отдела SEIKO EPSON Corporation («КП», 1998). На примере этого прецедентного слогана видимо, как употребление уже готовых прецедентных текстов с определенной коннотацией для рекламы не всегда достигает желаемого результата. Призыв программы «Жилье-2000», не осуществленной в действительности, заставляет реципиента рекламы задуматься над реальным наполнением этого слогана. Или такой странный слоган, как: БИЙСКЭНЕРГОМАШ BIYSKENERGOMASH («КП», 18.12.2010).

«Бийскэнергомаш» является официальным представителем ЗАО «Завод Блочно-модульных котельных ЭнергоЛидер» в Центральном регионе. Целесообразность подобного написания в русскоязычной газете названия компании, ориентированной на российского потребителя, лишено рационального смысла, но флер иностранности повышает аттрактивность для некоторых слоев общества.

Слоган, как правило, выделяется из всего остального текста рекламаного объявления. Например: ПРОДАЕТСЯ ПРОИЗВОДСТВЕННАЯ БАЗА В Г. МИНСКЕ земельнЫЙ участок - 1,6 га; административно-бытовой корпус - 1200 кв. М; производственные цеха и склады - 3000 кв. м.; растворобетонный узел («КП», 18.12.2010).

Существует практика выделения отдельных слов в корпусе самого слогана. Это позволяет вести речь о неких условных ключевых словах в самом слогане. Чаще всего это названия рекламируемых товаров либо инвитационные (анг. "invite" - приглашать) 
фрагменты (Розенталь, Кохтев). Целью инвитационных фрагментов служит привлечение внимания потенциального потребителя к самому рекламному слогану и последующему рекламному материалу. Примером выделения инвитационных приглашающих фрагментов может служить такой, довольно объемный слоган (объемность и есть одна из причин их выделения): Получите бесплатно наш каталог международных бестселеров, и Вы будете уверены (если войдете в число первых 1000 ответивщих) в том, что ВЫИГРАЕТЕ один из шести прекрасных ПРИЗОВ («КП», 18.10.2010). Или рекламный слоган одной из многочисленных заочных школ компьютерного программирования: КОМРЬЮТЕР ... и за партой сидеть не надо («КП», 18.10. 2010). В последнем случае аттрактивность инвитационного слова, кроме графических средств, подчеркнута и позиционно (первое место) и пунктуационно (многоточие).

Анализируя слоганы в газетной речи как отдельное языковые факты, можно выделить несколько основных типов их организации по превалированию того или иного аспекта в аттрактивности (привлекательной функции) и, кроме того степени его напряженности. Условно эти типы предлагаем назвать: констатирующие (установленные) слоганы; презентирующие слоганы; прецедентные слоганы.

Как уже говорилось выше и как явствует из предлагаемого названия, констатирующие (установленные) слоганы почти чисто информативны и лишь обозначают представляемый объект. Тем не менее, в массиве этих слоганов могут использоваться интересные стилистические, графические и собственно рекламные приемы. Слоганы подобного рода могут состоять из одного названия фирмы, характеристика которой дается в последующей рекламной информации, например: СамараЭнергоМаш («КП», о8.08.2010). Фирма специализируется на поставке энергетического оборудования: турбокомпрессоров, нагнетателей, вентиляторов и запчастей к ним. Констатирующие слоганы могут включать в себя и то и другое, например: Спецпредложение Сардельки «Сочнные» («КП», 2010); UZBEKISTANAIRWAYS Mосква - Ташкенm («КП», 2010). В последнем случае явно вычленяется в составе слогана инвитационный фрагмент, выделяемый двояко: как более крупным шрифтом, так и латинским написанием англизированного названия среднеазиатской авиакомпании.

Слоганы обычно довольно изолированы от последующего рекламного текста. Например, слоган, где отграниченность показана пунктуационно: Нарды 50000000о! («КП», 2011). Вообще некоторые слоганы (особенно презентирующие, в силу подчеркнутого в них эмоционального момента, и прецедентные, в силу их опоры на прецедентный текст) в последующей рекламной информации не нуждаются. Тем более интересен пример, где связь слогана с корпусом рекламного объявления нарочито подчеркивается (опять-таки пунктуационно), таким образом слоган дешифруется последним объявлением: Акционерное общество «Барнаулстроммаш» предлагает: ... («КП», 2011); ср.: Открытое акщионерное общество «СТРОММАШИНА» ... предлагает поставку электротехнического оборудования марки .

Одним из фактов последнего времени является вмонтирование в слоганы иноязычных элементов. Эти иноязычные элементы могут включаться в качестве названия фирмы в текст русскоязычного слогана. Примером может послужить уже цитировавшийся UZBEKISTANAIRWAYS Москва - Ташкент («КП», 10.02.2010); ср.: Авиакомпания Uzbekistan 
Airways сообщила о снижении стоимости ... Предлагаем дешевые билеты на самолет Москва Ташкент - Москва по цене .... где налицо двойное вторжение иностранного языка в начале в тюркоязычную среду, а затем в качестве названия в русский язык; или: Раковины ббирмы IDO (Финляндия) («КП», 08.08.2010); ср.: Раковины IDO (Финляндия). В каталоге представлены раковины от крупнейшего ффинского производителя IDO, а также все необходимые аксессуары для монтахса.

Одним из случаев билингвальное дублирование - воспроизведение в двуязычном варианте слогана. Это повышает аттракцию данного слогана путем графического выделения латиницы среди кириллицы и несомненно высокой привлекательности всего заграничного. Иноязычный компонент может представлять собой чистую транслитерацию названия фирмы: Бийскэнергомаш, BIYSKENERGOMASH («КП», 2010), ср.: «БийскЭнергоМаш, производственный центр» - о том, насколько повышает аттракцию такой транслитерационный уродец, можно поспорить. Билингвальное дублирование может также представлять собой перевод названия с одного языка на другой, например: Волга сервис VOLGA SERVICE («КП», 08.08.2010), ср.: Сервисный иентр Волга Сервис выполняет ремонт бытовой техники, электроники... Случай, где невозможно говорить о языке, с которого сделан перевод. С одной стороны, русскоязычное название стоит в препозиции, с другой стороны, аналитическая конструкция позволяет говорить именно об англоязычной основе этого слогана.

Иноязычное влияние может включаться в текст рекламы не только на лексическом или на транслитерационном, но и иероглифическом уровне. Например: Элитный иентр урологии г гинекологии («АиФ», 12.04.2010). Своеобразные иероглифы, обозначающие союз «и», характерны для европейских языков, где он выражается тремя (англ. and, нем. und) или двумя (фр. еt) или (словац. а) буквами, и использование подобных иероглифов весьма экономит место. Целесообразность использования французского иероглифа є в русском языке нулевая, и здесь можно говорить лишь о некой атрактивной функции подобного иероглифа, которая опять-таки, как и в случае с BIYSKENERGOMASH`em, заключается в желанном флере заграничности, который в подобных контекстах не нужен и смехотворен. Впрочем, пугающе может выглядеть и чисто русский слоган, чего стоит только принципиально непереводимый ни на какие земные языки АО МЗЭП-КРЖИЖИК («И», 05.05.2010), ср.: Закрытое Акиионерное общество «МЗЭП-КРЖИЖИК».

В качестве инвитиционных фрагментов могут использоваться логотипы самих фирм (например: Ford, Coca-Cola), но действие таких инвитационных фрагментов сказывается лишь в том случае, если номинат фирмы в достаточной степении «раскручен». Тогда он приобретает семантику, индуцированную в нем слоганом, приобретает устойчивую положительную коннотацию и становится знаком с определенным значением (высокого качества).

Название фирмы в качестве инвитационного фрагмента может претерпевать транслитерацию. Например: Лидер, который сделает Вас лидером! Копировальные аппараmы МИНОЛТА («И», 02.02.2010). Но это является нетипичным случаем для современной российской рекламной практики - заграничная фирма-производитель пишет свое название кириллицей, в то время как даже русские фирмы, ориентированные на отечественного потребителя, в целях повышения аттракции транслитерируются на латиницу 
(преимушественно по законам английского языка - пресловутый BIYSKENERGOMASH) (см. выше).

Фирменный стиль BMW:

Примером фирменного стиля является торговая марка «ВMW» «Байериш Моторен Верке», (BMW, Bayerisch Motoren Werke AG), немецкая автомобильная компания, специализирующаяся на производстве легковых и спортивных автомобилей, автомобилей повышенной проходимости и мотоциклов.

В качестве элементов, заостряющих внимание на рекламных слоганах подобного типа, используются определенные пунктуационные приемы. Чаще всего это знаки восклицания. Например: ZASS Cогреет Вас! Радиатор Вы купили, в подарок получили?! («КП», 08.07.2010), ср.: Если у Вас будет пейджер, Ваша семейная жизнь .... РАДИАТОР ВЫ КУПИЛИ, А ПОДАРОК ПОЛУЧИЛИ? .... ZASS СОГРЕЕТ ВАС!. Здесь экспрессивный синтаксис используется в качестве дополнительного средства к рифмовке. Примечателен также такой мегаэкспрессивный слоган: IBN TRAVEL OAЭ Авиабилеты, отдых всей семьей! Детям скидки ну очень большие!!! Тур за автомобилями - ну очень дешево!!! Израиль.

Презентирующие слоганы представляют собой самый распространенный вид печатных рекламных зазывов. В отличие от констатирующих, они дают определенные (положительные) характеристики рекламируемых объектов. В них наиболее четко вычленяются компоненты, как привлекающие внимание к самому факту рекламы (инвитационные фрагменты), так и апеллирующие к потребителю (кодовые слова). В составе презентирующих слоганов есть рифмованные фразы, обращенные к мнемонике потенциального потребителя.

Рассмотрим прецедентные слоганы, классифицированные по видам (Розенталь, Кохтев, 1981):

Прецедентные слоганы - деформанты: слоганы, основанные на прецедентных текстах. Прецедентный текст - выражение, которое широко известно, отнесенность его к автору весьма ослаблена, отнесенность к денотату также нечетка, вследствие чего он служит удобным объектом для языковой игры. Деформант являет собой выражение, где некий фрагмент исходного прецедентного текста опущен и вместо него помещен актуализирующий компонент, своеобразная скрепа, увязывающая прецедентный текст с настоящей языковой реалией. Примером подобных слоганов могут служить: Мосбфильм предупреждает: Акиия «Пойдем в кино» началась («КП», 08.08. 2010). Как видим от прецедентного текста осталось единственное слово, но, тем не менее, он узнавает за счет устойчиво внедренного в сознание выражения «Минздрав предупреждает»-«Курение опасно для вашего здоровья» и типологического сходства аббревиатур «Мосфильм» и «Минздрав». Или: Каждой российской семье к 2000 году качественный струйный принтер EPSON Stylus Color 300 из решений рекламного отдела SEIKO EPSON Corporation («КП», 08.08. 2010) (см. выше). В последнем случае существует явная аллюзия не только на известный лозунг, но и на саму программу ЦК КПСС «Жилье-2000».

Прецедентные слоганы - трансформанты. Это слоганы, основанные на прецедентных текстах, где актуализирующий, то есть конкретизирующий компонент, помещен рядом с прецедентным текстом - исходным выражением и, чаще всего, пунктуационно отграничен от прецедентного текста. Примерами таких прецедентных слоганов - 
трансформантов могут служить следующие фразы: Холдинг Полигон Торговый дом ... и Вы всегда в форме («КП», 08.08. 2010), ср.: ЗАО «ТОРГОВЫЙ ДОМ ХОЛДИНГ-ПОЛИГОН»-Москва ЦАО - Лекарства и медииинские изделия. или: Europa plus. Настройся на лучше («КП», 12.10. 2009). В обоих случаях прецедентный текст - фразеологизм, то есть самый безотносительный и легко ассоциируемый с чем угодно вид прецедентного текста. Таким образом разрушительное влияние полиассоциативности - ассоциирования результата языковой игры как с актуальным денотатом, так и с прецедентным текстом, как неотменного условия языковой игры с прецедентными текстами на основную функцию рекламного слогана - аттракцию весьма ослабляется. В отличие от трансформантов - заголовков, где прецедентный текст почти всегда стоит в препозиции по отношению к актуализирующему компоненту, в случаях с трансформантами-слоганами подчеркивается явный примат актуализирующего компонента - в данном случае номината фирмы.

Слоганы-трансноминаты - следующий вид прецедентных слоганов - представляют собой прецедентные тексты, формально не искаженные языковой игрой, но а создающемся контексте приобретающие значение несколько отличное от значения прецедентного текста. То есть актуализируюший компонент материально в них не выражен. А проанализированном массиве рекламных слоганов удалось встретить лишь один подобный экземпляр (подобная формально не выраженная языковая игра вообще относительно редка): Цени Момент («КП», 12.10. 2010) - реклама клея «Момент».

В данном случае, как и в ранее рассмотренных случаях трансформации, имеет место изменение семантики исходного фразеологизма как самого «безобидного» прецедентного текста - Момент (прецедентный текст) = мгновение / Момент (актуализируюший компонент) - клей. В соответствии с этой меной меняется также и значение слова «цени», приобретающего, возможно, помимо желания авторов слогана, некий денежный эквивалент. Примечательно также, что и текст самого рекламного объявления, помещенного под этим зашифрованным слоганом, представялет собой ребус.

Одним из компонентов языка рекламы, и рекламы печатной в частности, является слоган.

В печатном слогане выделяются компоненты, привлекающие внимание как к самому факту существования рекламы, так и к рекламируемому товару. Компонент, привлекающий внимание к самому факту существования рекламы, назван инвитационным фрагментом. Инвитационный фрагмент представляет собой выделенный полиграфическим способом тот или иной элемент слогана: словосочетание, слово или часть его. Иногда инвитационный фрагмент может представлять собой название фирмы. Компоненты слогана, воздействующие на реципиета рекламы, побуждающие его к требуемым действиям, называются кодовыми словами.

\section{ADVERTISING SLOGAN IN MASS MEDIA}

SUMMARY One of the components of the language of advertisements is its slogan. Attention catching phrases appear in an advertising slogan in order to attract the advertised product. An element that brings attention to itself is 
also known as an "invitation" element. This is a special method of print media: a collocation, phrase, word or its part. Sometimes the "invitation" element can stand for a company's name. According to the degree of objectivity and the nature of information, we distinguish between informative and culturo-lingual slogans.

\section{ЛИТЕРАТУРА}

I Алефиренко Н. Ф., 2010, Лингвокультурология. Ценностно-смысловое пространство языка, Москва.

I Гуревич С. М., 2004, Газета: Вчера, сегодня, завтра, Учебное пособие для вузов, Москва, $288 \mathrm{c}$.

I Козинская Е. А., 2001, Цитатное слово в газетном заголовке и рекламном тексте, Тверь.

I Литвинова А. В., 1996, От заголовка к слогану, „Вестник Московского университета“, No 5 , C. 30-35.

I Лысакова И. П., 1981, Язык газеты, Социолингвистический аспект, Ленинград, 250 с.

I Манькова Л. А., 2001, Современный газетный заголовок: его функция и структура. Семантика слова и семантика текста, М., Вып. 4., С. 10-16.

I Музыкант В. Л., 1992, Газетный заголовок и его особенности, „Актуальные проблемы мингвистики и журналистики“, М., Ч. 2., С. 208-214.

I Розенталь Д. Э. - Кохтев Н. Н., 1981, Язык рекламных текстов, Москва.

I Сальникова О. Г., 1983, Как рождаются заголовки, «Русская речь», № 3., С. 60-62.

I Adamka P., 2011, Ruská publicistika (jazyk), Nitra.

I Chovanec M., 2015, Skratky ako odraz sociokultúrnych procesov (rusko-slovenské porovnávanie). Acta Facultatis Philosophicae Universitatis Prešoviensis. Monographia 203, AFPh UP 502/533, Prešov, s. 157.

I Mistrík J., 1982, Jazyk a štýl novín, rozhlasu a televízie. Ku konferencii novinárov a jazykovedcov, „Pravda“, roč. 63, č. 94, s. 5.

I Virostková A., 2013, Precedentné texty v jazyku tlače, Rigorózna práca. Prešov, s. 169. 